Муканбет кызы $Э^{\mathbf{1}}, \quad$ Н.Сарбаева ${ }^{\mathbf{1}}$

${ }^{1}$ КГУСТА им. Н. Исанова, Бишкек, Кыргызская Республика

\author{
Mukanbet kyzy $\mathbf{E}^{\mathbf{1}}$, N. Sarbaeva ${ }^{1}$ \\ ${ }^{1}$ KSUCTA n. a. N. Isanov Bishkek, Kyrgyz Republic \\ (erkin.mukanbetova@mail.ru)
}

\title{
FEATURES OF THE INFLUENCE OF CLIMATIC FACTORS AT DESIGN OF PUBLIC BUILDINGS (CASE STUDY: KYRGYZSTAN)
}

\section{ОСОБЕННОСТИ ВЛИЯНИЯ КЛИМАТИЧЕСКИХ ФАКТОРОВ ПРИ ПРОЕКТИРОВАНИИ ОБЩЕСТВЕННЫХ ЗДАНИЙ (ПРИМЕР: КЫРГЫЗСТАН)}

Бул макалада аз кабаттуу имараттардын тосуучу констурукцияларына таасир этҮҮчҮ факторлорунун бири болуп, алардын жылуулук чыгарууга көрсөткөн каршыльгьы каралган. Алар тосуучу конструкциялардын жылуулук чыгарууга көрсөткөн каршыльгы боюнча кичи блоктун (кирпич же кыш), жыгачтын, дубал панелдеринин оптималдуу калыңдыгы эсептелинип чыккан, алар үчүн климаттык анализ жасалган (температура, шамал, күн радиачиясы, жаан-чачын ж.б.). Булар конструкциянын көтөрүY жөндөмдүүлүгүнө таасир этээри, аны менен бирге эле, алар климаттык районго жараша эксплуатацияльк талаптарга жооп бериш керектиги каралган. Мисал катары, катаал климаттык өзгөчөлүктөргө ээ шаарлар альцган, булар берилген базалык чоңдуктар боюнча керектуY эксплуатациялык көрсөткүчтөр менен мүнөздөлгөн. Эсептердин жыйынтыктары гистограмма түрүндө жана бетон же арматурадагы максималдуу чыңалуулардын параметрлери боюнча каралган

өзөк сөздөр: туруктуулук, температура, шамал, күн радиациясы, жаан-чачын, тосмо конструкциялар, жылуулукту жоготуу, жылуулук изоляциялоочу материалдар, ири пландаштыруу боюнча чечимдер, жылуулук обочолоочу материал - базальт буласы, жылуулук обочолоочу маттар - жылуулук берүү.

В статье рассматривается климатический факторов, влияющий на ограждающие конструкции малоэтажных домов, их устойчивость к тепловыделению. Оптимальная толщина небольшого блока (кирпича), дерева, стеновых панелей рассчитывалась исходя из устойчивости ограждающих конструкций к тепловыделению, которая подвергалась климатическому анализу (температура, ветер, солнечная радиация, осадки и т. д). Они влияют на несущую способность конструкции, которые должнны соответствовать эксплуатационным требованиям в зависимости от климатической зонь. $B$ качестве примера были изучены города с суровыми климатическими характеристиками, которые характеризовались требуемой производительностью при заданных исходных значениях, а также результать расчетов представляются в виде гистограмм и параметров максимальных напряжений в бетоне или арматуре.

Ключевые слова: устойчивость, температура, ветер, солнечная радиация, осадки, ограждающая конструкция, теплопотеря, теплоизолячионный материал, объемнопланировочное решение.

The Article discusses one of the Factors affecting the enclosing structures of Low-rise Buildings, their resistance to Heat generation. Also, the optimal thickness of a small Block (brick), wood, wall panels was calculated based on the resistance of the Enclosing Structures to Heat generation, which was subjected to Climatic analysis (Temperature, Wind, Solar radiation, 
Precipitation, etc. These factors affect the bearing capacity of the Structure, as well as as an example, were obtained Cities with severe Climatic Characteristics, which were characterized by the required performance at given initial values. The results of the calculations are presented in the form of Histograms and Parameters of Maximum Stresses in Concrete or Reinforcement.

Key words: Stability, Temperature, Wind, Solar Radiation, Precipitation, Enclosing Structures, Heat loss, Heat-insulating materials, Space-planning solutions.

One of the Factors affecting the Enclosing Structures of low-rise Buildings is their resistance to Heat generation. Was calculated using climatic analysis (Temperature, Wind, Solar radiation, Precipitation, etc.) based on the "resistance of the enclosing structures to Heat dissipation", the optimal thickness of a small Block (Brick), Wood, wall panels. These Factors affect the Loadbearing Capacity of the structure and must meet the performance requirements depending on climatic Zone. For example, were obtained cities with severe climatic features, which characterized by the required performance Indicators for a given Baseline Value [1. p. 3].

When designing external enclosing Structures, it is necessary to take into account the protocol of their operation. Climatic Factors actively influence the external enclosing structures; the calculation of their operation includes the calculation of the stability of the structure. A decrease in strength occurs due to Free bending, Precipitation, Twisting, Vibration, Cracking, etc. leads to Reduction of heat loss in Winter is taken into account by space-planning solutions, with the Rational Use of thermal insulation materials with the smallest area of protective structures (thermal insulation plates - Basalt Fiber, insulation mats - Heat transfer 0.041 and 0.37).

In addition to strength and stability calculations, additional calculations performed depending on Geographic and Climatic conditions. For example, along with the basic calculations of the Outer Walls of Brick Houses, Heat Engineering calculations are carried out, mainly in the corners of the house, in the bands of additional shelving structures for Monolithic Houses. All over the World, there is a Tendency to an increase in the resistance of Shelter Structures to Heat Transfer, and in Kyrgyzstan this indicator is 2.1-5.6 $\mathrm{m}^{2} \quad / \mathrm{W}, 3.2-8.2 \mathrm{~m}^{2} \quad / \mathrm{W}$, depending on the Heat Transfer Time for External Shelters. [2. p.36].

When designing protective structures, temperature requirements must be taken into account, i.e. calculate the temperature distribution over individual sections or over the total volume of structures. Such a calculation meets sanitary and hygienic requirements and improves the quality of thermal protection of the enclosing structures. Under Natural Conditions, the heat transmitted by protective structures is always non-stationary, since Environmental Conditions are constantly changing - the ambient Temperature, the intensity of sunlight, the strength and direction of the wind. In practice, the calculation of shelter structures is carried out according to design parameters that characterize climatic conditions.

The initial values of climatic factors are entered online in accordance with building codes and regulations [1 p.12].

We carry out Thermal and Technical surveys of Buildings made of Bricks, Panels and Wooden Walls. Let's study the main climatic zones of Kyrgyzstan as a construction region. In this case, for the city of Bishkek $\mathrm{tn}=-23$; for the city of Balykchy $\mathrm{tn}=-9$; and for Toguz-Toro $\mathrm{tn}$ $=-31$. (tn - Outdoor Temperature).

Thermal and Technical calculations of external structures are performed according to the following algorithm.

Heat loss of enclosing structures account results:

1) Bishkek $\mathrm{R}_{0 \text { тр }}=1,18 \mathrm{~m}^{2}{ }^{\circ} \mathrm{C} / \mathrm{Bt}, \mathrm{R}_{0 \text { тр,прив }}=2,44 \mathrm{~m}^{2}{ }^{\circ} \mathrm{C} / \mathrm{Bt}$;

2) Balykchy $R_{0 т р}=0,78 \mathrm{~m}^{2}{ }^{\circ} \mathrm{C} / \mathrm{Bt}, \mathrm{R}_{0 \text { тр,прив }}=2,63 \mathrm{~m}^{2}{ }^{\circ} \mathrm{C} / \mathrm{Bt}$;

3) Toguz-Toro $\mathrm{R}_{0 \mathrm{Tp}}=1,41 \mathrm{~m}^{2}{ }^{\circ} \mathrm{C} / \mathrm{Bt}, \mathrm{R}_{0 \text { тр,прив }}=2,97 \mathrm{~m}^{2}{ }^{\circ} \mathrm{C} / \mathrm{Bt}$.

We determine the optimal Wall thickness $\mathrm{R}_{0}$ based on the total Heat transfer resistance, equating the required $\mathrm{R}_{0 т \mathrm{p}}$, drive and the required thermal conductivity resistance $\mathrm{R}_{0 т р}$. 
First option: for external plaster of brick walls $\delta \mathrm{i}=0.015 \mathrm{~m}$ and for internal plaster is equal $\delta \mathrm{c}=0.015 \mathrm{~m}$.

Table 1. Estimated brick wall thickness

\begin{tabular}{|l|l|l|l|l|}
\hline Construction area & $\delta_{\mathrm{K}}(\mathrm{m})$ & $\delta_{\text {кконстр }}$ & $\delta_{\text {к1 }}(\mathrm{m})$ & $\delta_{\text {к1 констр. }}$ \\
\hline Bishkek & 1,05 & $1,03 \mathrm{M}$ & 0,46 & $0,51 \mathrm{M}$ \\
\hline Balykchy & 1,14 & $1,16 \mathrm{M}$ & 0,273 & $0,38 \mathrm{M}$ \\
\hline Toguz-Toro & 1,30 & $1,29 \mathrm{M}$ & 0,569 & $0,64 \mathrm{M}$ \\
\hline
\end{tabular}

where $\delta \mathrm{k}$ is the estimated thickness of the brick wall;

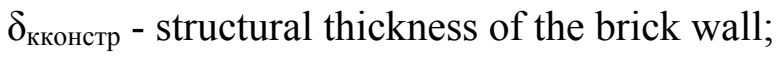

$\delta_{\mathrm{k} 1}$ - design wall thickness without taking into account the degree-day value during the heating season [1 p.14];

$\delta_{\mathrm{K} 1}$ - constru is the structural thickness of the brick wall.

Second option: Plasters of the inner wall from expanded Clay Concrete with (Lime-Sand mortar $\delta \mathrm{i}=0.015 \mathrm{~m})$ and external (Cement-Sand mortar $\delta \mathrm{ts}=0.015 \mathrm{~m})$.

Table 2. Estimated thickness of expanded Clay Concrete Wall

\begin{tabular}{|l|c|l|l|l|}
\hline Construction area & $\delta_{\mathrm{K} / \sigma}(\mathrm{M})$ & $\delta_{\mathrm{K} / \text { констр }}$ & $\delta_{\mathrm{K} / \sigma 1}(\mathrm{M})$ & $\delta_{\mathrm{K} / 61 \text { констр. }}$ \\
\hline Bishkek & 0,38 & $0,40 \mathrm{M}$ & 0,46 & $0,50 \mathrm{M}$ \\
\hline Balykchy & 0,41 & $0,45 \mathrm{M}$ & 0,273 & $0,30 \mathrm{M}$ \\
\hline Toguz-Toro & 0,47 & $0,50 \mathrm{M}$ & 0,569 & $0,60 \mathrm{M}$ \\
\hline
\end{tabular}

where $\delta_{\mathrm{k} / \mathrm{b}}$ - where $\delta \mathrm{k}$ is the calculated thickness of the expanded clay concrete wall, taking into account the daily value in degrees during the heating season;

$\delta_{\mathrm{K} / \mathrm{bkonstr}}$ - structural thickness of expanded clay concrete wall;

$\delta_{\mathrm{K} / \sigma 1}$ - calculated thickness of expanded clay concrete wall without taking into account daily degrees during the heating season;

$\delta_{\mathrm{K} / 61 \mathrm{constr}}$ - structural thickness of the expanded clay concrete wall;

Indicators are calculated by algorithms [2 p.13]:

1. Bishkek - $\delta_{\mathrm{yT}}=0.044 \mathrm{~m}$;

2. Balykchy $-\delta_{\mathrm{yt}}=0.051 \mathrm{~m}$;

3. Toguz-Toro $-\delta_{\mathrm{yT}}=0.063 \mathrm{~m}$.

Depending on Climatic Conditions, the microclimate of Low-Rise Housing is provided by an algorithm. Algorithmic calculations for Construction sites with the same Climatic Conditions and same microclimate requirements, taking into account the cost of Buildings under construction, show an increase in the cost of Shelter Structures, which, depending on use of highly efficient thermal insulation materials, leads to thickening of the Walls.

The reliability of the wall panels was developed by the modernization method (the method of Znamensky and Sukhov). The calculation results are presented in the form of a histogram and parameters of maximum stresses in concrete or reinforcement:
a) minimum and maximum values;
b) medium size;
c) variance;
d) standard deviation;
e) asymmetry; 
e) excess;

f) coefficient of variation.

$$
\begin{aligned}
& \text { If } \sigma_{\mathrm{n}}<0, \sigma_{\mathrm{bn}} \mathrm{A}_{\mathrm{bn}}+\sigma_{\mathrm{sl}} \mathrm{A}_{\mathrm{sl}}>\mathrm{A}_{\mathrm{bn}} \mathrm{R}_{\mathrm{p}}+\mathrm{A}_{\mathrm{sl}} \mathrm{R}_{\mathrm{sl}} \\
& \text { if } \sigma_{\mathrm{n}} \geq 0, \text { according } \sigma_{\mathrm{sl}}>\mathrm{A}_{\mathrm{sl}}, \mathrm{P}=1-(\mathrm{n} / \mathrm{m}) \text {; }
\end{aligned}
$$

Where $\mathrm{n}$ is the volumetric quantity; $\mathrm{m}$ is the number of experiments.

When assessing the reliability of structural elements of group 1, it is necessary to characterize the strength of the structure, which determines the adjacent positions.

If we say that the strength state of a structural element is as follows:

$$
f\left(\mathrm{Q}_{\mathrm{R}}\right) \leq \varphi\left(\mathrm{R}_{\mathrm{b}}, \mathrm{R}_{\mathrm{s}}\right)
$$

where $f(\mathrm{QR})$ and $\varphi(\mathrm{Rb}, \mathrm{Rs})$ are some indefinite functions, usually not linear, that relate the total forces to the design resistance of the reinforcement in the cross-section of elements and in concrete.

$$
\mathrm{S}\left(\mathrm{Q}_{\mathrm{R}}, \mathrm{R}_{\mathrm{b}}, \mathrm{R}_{\mathrm{s}}\right)=f\left(\mathrm{Q}_{\mathrm{R}}\right)-\varphi\left(\mathrm{R}_{\mathrm{b}}, \mathrm{R}_{\mathrm{s}}\right)
$$

The function indicates the safety factor of the structure.

$$
\begin{aligned}
& \text { Then the functional } \mathrm{P}=0 \int^{\infty} \mathrm{P}(\mathrm{s}) \mathrm{ds} \text {, } \\
& \text { or } \mathrm{P}=\iint \ldots \int \mathrm{P}[\mathrm{S}(\mathrm{QR}, \mathrm{Rb}, \mathrm{Rs})] \mathrm{dQ} 1 \ldots \mathrm{dQm} \mathrm{dRb} d \mathrm{Rs}
\end{aligned}
$$

$\mathrm{S}(\mathrm{QR}, \mathrm{Rb}, \mathrm{Rs}) \geq 0$ - strength of a structural element.

The exact derivative of the solid form can be found if the value under the integral (6) is integrated and can be obtained, but often these formulas are too large and inconvenient for practical application. Therefore, the use of statistical testing methods in estimating $\mathrm{P}$ is effective because it is a universal method for using a computer. The nature of this is simple and initially distributes the random numbers (0-1) evenly using standard programs, making it easier to compute. Is checked the inequality of $\mathrm{QR}$ and strength $\mathrm{Rb}$ of each random stress state with the characteristic Rs (3), which determines the destruction of structural elements.

Possible start V was determined by the following formula:

$$
\mathrm{V}=\mathrm{m} / \mathrm{n} \text {, }
$$

where $\mathrm{n}$ - the number of tests; $\mathrm{m}$ - the number of unfulfilled conditions.

$$
\text { We define the guarantee as } \mathrm{P}=1-\mathrm{V}
$$

The principle of the guarantee assessment algorithm is as follows. In tests of the first millennium, access denial $\mathrm{V}$ determined for $\mathrm{n}$, which is a possible defect $\mathrm{V}$ not exceeding $\Delta$.

$$
\mathrm{n}=4 \mathrm{~V}(1-\mathrm{V}) / \Delta^{2}
$$

where $\Delta$ is a well-defined deviation probability $\mathrm{V}$ (detectable access defect $\mathrm{V}$ ).

The value is conveniently found by the following formula:

$$
\begin{gathered}
\Delta=10^{-\mathrm{k}}, \\
\mathrm{k}=\mathrm{r}+2,
\end{gathered}
$$

where $\mathrm{r}$ is the number of zeros after the decimal point of size $\mathrm{V}$, which is determined after the first thousand experiments. For example, if $\mathrm{V}=0.02 \mathrm{r}=2, \mathrm{k}=4 ; \Delta=10^{-4}$.

The limited position of structural elements in the second group is due to the type of deformation and cracking.

$$
f\left(\mathrm{У}_{\kappa}\right) \leq \varphi\left(\left[\mathrm{У}_{\kappa}\right]\right),
$$

where $f(\mathrm{Vk})$ and $\varphi([\mathrm{Vk}])$ are some nonlinear functions, usually nonlinear, that combine the parameters of deformation and fracture in structural elements and have a finite (possible) value.

$$
\mathrm{K}\left(\mathrm{У}_{\mathrm{K}}\right)=f(\mathrm{Yk})-\varphi([\mathrm{Yk}])
$$

Functions characterize the reserves of stiffness and crack resistance of structures. Then the functional $\mathrm{P}=0 \int^{\infty} \mathrm{P}(\mathrm{k}) \mathrm{dk},(14)$

$$
\text { or } \mathrm{P}=\int \ldots \int \mathrm{P}[\mathrm{K}(\mathrm{Yk})] \mathrm{d} \mathrm{Y} 1 \ldots \mathrm{d} \mathrm{Yt},
$$

$\mathrm{K}(\mathrm{Uk}) \geq 0$ increases the rigidity and crack resistance of the structure. 


\section{Bibliography}

1. Badev V.V., Egorov Yu.A., Kazakov S.V. Environmental Protection during the operation of Buildings. - Moscow: Energoatomizdat, 1990. -130 p.

2. Research of the main parameters of the Microclimate of the Premises [Text] / B.S. Matozimov, M.D. Kutuev, E. Mukanbet K. and others - B: Izvestiya Vuzov. No. 1, 2012. - p. 12-14.

3. Research of Thermophysical calculations of enclosing structures affecting the Microclimate of the Premises [Text] / B.S. Matozimov, M.D. Kutuev, Mukanbet K. E. and others B: Izvestiya Vuzov. No. 1, 2012. - p. 36-39.

4. M.D. Kutuev, B.S. Matozimov. Conceptual approach to the problems of Building Physics. // Proceedings of the International Conference on the Propagation of Elastic and Elastoplastic Waves. - B., 2009, T35. - p. 297-300.

5. B.S. Matozimov, Zh.Y. Mamatov, D.Sh. Kozhobaev, B.S. Ordobaev, A.M. Misirova Thermal Protection of Low-Rise Buildings from local materials - B: Izvestiya Vuzov, 2010. No. 4, p.19-23.

6. B.S. Matozimov, Zh.T. Tentiev, Mitrokhin B.A. Research and climatic analysis of factors affecting the bearing capacity of buildings. Problems of Design, Construction and operation of Highways and Railways in Mountainous Areas. // Collection of scientific papers. Issue No. 11, Bishkek - 2002. p.140-146.

7. B.S. Matozimov. Methodological Instructions for laboratory Work in the discipline "Architectural physics" // section "Heat engineering" - B .: KSUBTA, 2002 . 28 p.

8. Муканбет к.Э. ЖергиликтүҮ матеиалдарды колдонуп коомдук имараттарды долбоорлоодо негизги өзгөчөлүктөрүн иликтөө [Текст] / Муканбет к. Э., Э.Т.Токторалиев // Вестник КГУСТА. - Бишкек: 2019. - №4(66). - с.634-639.

9. Темикеев К. Экспериментальные исследования предельных состояний термоструктурных панелей из полистирола при центральнос сжатии [Текст] / К.Темикеев, Эргешбай уулуА., Т.Ж. Алькассар, А.А.Мещеряков // Вестник КГУСТА. - Бишкек: 2018. - №4(62). - c.83-87. 